CHAPTER 12

\title{
The Ocean and Climate Change Law
}

\author{
Exploring the Relationships
}

\author{
Daniel Bodansky
}

Physically, the ocean and climate change are highly interconnected. On the one hand, the ocean plays a central role in the climate system, as a sink for both heat and carbon dioxide $\left(\mathrm{CO}_{2}\right)$. Since 1970, it has absorbed more than 90 percent of the accumulated energy from anthropogenic warming ${ }^{2}$ and about 30 percent of anthropogenic carbon dioxide emissions. ${ }^{3}$ In doing so, it has helped to moderate climate change significantly. But this benefit to the climate has come at a serious cost to the ocean itself. Global average sea-surface temperature has already risen by $0.5^{\circ} \mathrm{C}$ since $1980,{ }^{4}$ and the ocean is 30 percent more acidic than 15 o years ago. ${ }^{5}$ As climate change continues, its impact on the ocean will intensify. ${ }^{6}$ Sea levels will rise, causing coastlines to change, flooding and eroding coastal areas, and possibly leading to the disappearance of lowlying island States. ${ }^{7}$ Coral reefs will be decimated as a result of warmer waters

1 This chapter was completed in 2019 and has not been updated to address subsequent developments. It draws on ideas developed in the context of a collaborative project with Susan Biniaz and Climate Advisers, funded by the Ocean Conservancy. However, the author is solely responsible for the specific contents of this chapter and the views expressed herein.

2 Intergovernmental Panel on Climate Change (IPCC), Climate Change 2013: The Physical Science Basis, Summary for Policymakers, TF Stocker, D Qin, G-K Plattner et al. (eds) (Cambridge University Press, 2013) 8.

3 Ibid 12; see also T Devries, M Holzer and F Primeau, 'Recent Increase in Oceanic Carbon Uptake by Weaker Upper-Ocean Overturning' (2017) 542 Nature 215 (ocean sink has absorbed 40 percent of $\mathrm{CO}_{2}$ emissions since the beginning of industrial era).

4 US Environmental Protection Agency, Climate Change Indicators in the United States (2016).

5 L Morello, 'Oceans Turn More Acidic than Last 80o,ooo Years' Scientific American (22 February 2010).

6 See generally IPCC, The IPCC Special Report on Ocean and Cryosphere in a Changing Climate (H-O Pörtner, DC Roberts, V Masson-Delmotte et al. (eds) (2019), https://www.ipcc.ch/srocc/ (all websites accessed 26 January 2021 unless otherwise noted).

7 J Goodell, The Waters Will Come: Rising Seas, Shrinking Cities, and the Remaking of the Civilized World (Little, Brown \& Company, 2017). 


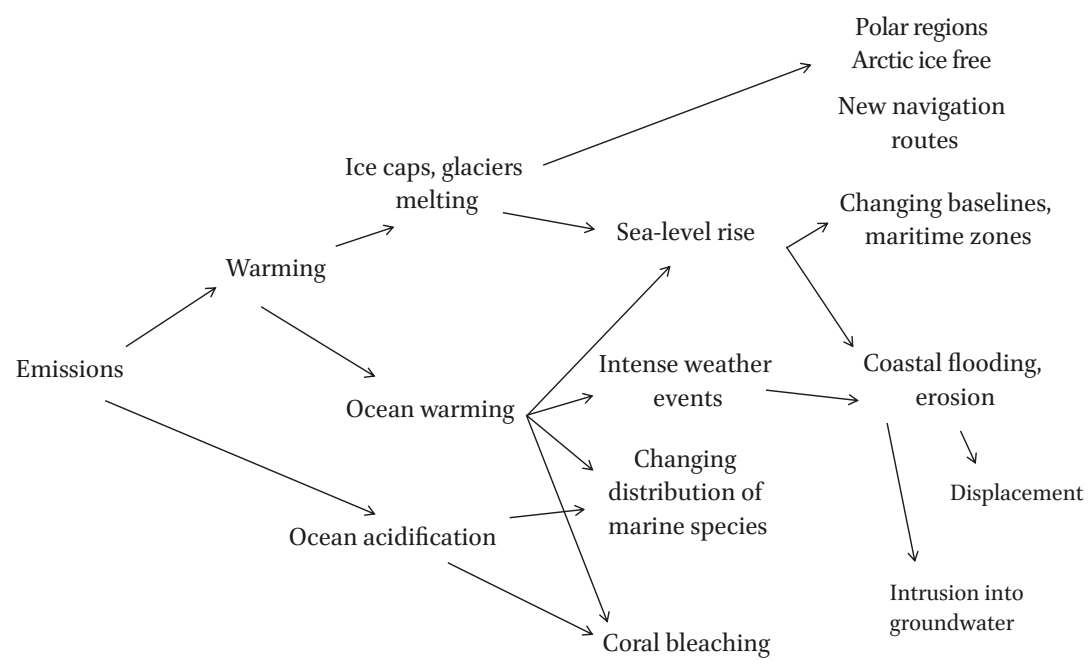

FIGURE 12.1 Diagram of climate change related impacts

and ocean acidification. ${ }^{8}$ And the abundance of marine species will decline and their distribution shift to higher latitudes (Figure 12.1). ${ }^{9}$

Despite these physical interconnections, neither the ocean regime nor the climate change regime has historically had much to say about the other. The Law of the Sea Convention (LOSC) ${ }^{10}$ - the so-called 'constitution for the ocean'11 - was adopted before climate change had become a significant international issue and does not mention it at all. And the basic instruments of the UN climate change regime contain few references to the ocean. The United Nations Framework Convention on Climate Change (UNFCCC $)^{12}$ mentions the ocean only once, in Article 4.1(d), which provides that parties shall 'promote

8 MJH van Oppen and JM Lough, Coral Bleaching: Patterns, Processes, Causes and Consequences (2nd ed, Springer, 2018).

$9 \quad$ IPCC, Climate Change 2014: Impacts, Adaptation and Vulnerability. Part A: Global and Sectoral Aspects. Contribution of Working Group II to the Fifth Assessment Report of the Intergovernmental Panel on Climate Change, CB Field, VR Barros, DJ Dokken et al. (eds) (Cambridge University Press, 2014) 414.

10 United Nations Convention on the Law of the Sea, adopted 1o December 1982, in force 16 November 1994, 1833 UNTS 3 (LOSC). In honour of David, I refer to the 1982 Convention without the initial words 'United Nations' or initial letters 'UN', which he thinks have been prejudicial to US acceptance of the Convention.

11 Remarks of Tommy Koh, Chair of the Closing Session, in The Law of Sea: Official Text of the United Nations Convention on the Law of the Sea with Annexes and Index (United Nations, 1983) xxxiv.

Adopted 9 May 1992, 1771 UNTS 107 (UNFCCC). 
sustainable management, and promote and cooperate in the conservation and enhancement, as appropriate, of sinks and reservoirs of all greenhouse gases ... including biomass, forests and oceans'. The Kyoto Protocol contains no references to the ocean. And the Paris Agreement mentions the ocean, not in the operative part of the agreement, but in a brief preambular paragraph 'noting the importance of ensuring the integrity of all ecosystems, including oceans. ${ }^{13}$

Recently, this situation has begun to change. In 2009, the World Ocean Conference adopted the Manado Declaration, ${ }^{14}$ which recognized the need for climate change adaptation and mitigation to be informed by 'ocean dimensions'. Later that year, ocean advocates organized the first Ocean Action Day at the annual conference of the parties (COP) to the UNFCCC, an event that has been repeated at subsequent COP s. In 2015, Chile sponsored the 'Because the Ocean' Declaration, which 23 States signed. ${ }^{15}$ During its CoP presidency in 2017, Fiji launched the Ocean Pathway initiative. ${ }^{16}$ And in 2019, representatives of more than 30 countries adopted the Brussels Declaration on Climate Change and Oceans Preservation, ${ }^{17}$ and the IPCC issued a special report on The Ocean and Cryosphere in a Changing Climate.

Now that the ocean has secured the attention of the UN climate change regime, the question becomes: How can the UN climate change regime better take the ocean into account? In 2009, prior to the Copenhagen conference, Freestone lamented that the ocean was the Cinderella of the UN climate change negotiations: it was never invited to the ball. ${ }^{18}$ Now that it has been invited, what dance does it want the UN climate change regime to play? Could climate change law do more to address ocean issues and, if so, in what ways? What are the respective roles of climate change law and ocean law in tackling the interconnections between climate change and the ocean? And given these physical interconnections, should the legal regimes governing climate change and the ocean be more closely tied?

This chapter begins to explore these issues at the frontiers of climate and ocean law. In general, it argues that the current division of labour between

\footnotetext{
13 Adopted 12 December 2015, [2016] ATS 24, preambular para 13.

14 Mnado Ocean Declaration, adopted 14 May 2009, https://www.gc.noaa.gov/documents/ o51409-manado_ocean_declaration.pdf.

15 The 'Because the Ocean' Declaration was signed by 23 countries at COP-21 in Paris in 2015. A second 'Because the Ocean Declaration' was launched by Chile in 2016 at COP-22.

16 See Ocean Pathway website, https://cop23.com.fj/the-ocean-pathway/.

17 Brussels Declaration, The Ocean and Climate Change, adopted 19 February 2019, https:// climateoceans.eu/documents.

18 D Freestone, 'Climate Change and the Oceans' (2009) 4 Carbon and Climate Change Law Review $383-386$.
} 
climate change and ocean law makes sense. In protecting the ocean against climate change, the most important task is to stop, or at least slow, climate change. Ocean law has limited ability to do so. ${ }^{19}$ Instead, mitigation of climate change is the job of the UN climate change regime, albeit one that it has performed with only modest success thus far. In contrast, ocean law is better equipped than climate change law to address the issue of how the ocean might adapt to the impacts of climate change. The role of the UN climate regime with respect to ocean adaptation is primarily that of support.

What should the UN climate change regime do differently to address ocean issues? This chapter argues that the most important thing the regime could do is to succeed in limiting climate change. This depends primarily on States implementing their existing commitments under the Paris Agreement, increasing their ambition over time, and developing a Paris rulebook that promotes transparency and accountability, not on ocean-specific measures.

That said, the chapter identifies two important ways that a stronger focus on ocean issues might assist the UN climate change regime both in meeting its climate objectives and in better protecting the ocean. First, the climate regime should do more to encourage the conservation and enhancement of ocean sinks, including potentially in areas beyond national jurisdiction, if that proves legally and technically feasible. Ocean sinks play a critical role in the carbon cycle. Although the degree to which human actions can promote ocean sinks remains uncertain, to the extent it proves possible to do so in a measurable, verifiable, and environmentally-friendly manner, this would have enormous climate - and, by extension, ocean - benefits. Second, the UN climate change regime should give extra consideration to reducing $\mathrm{CO}_{2}$ emissions relative to other greenhouse gases, given their role in causing ocean acidification. ${ }^{20}$

The chapter proceeds as follows. Part 2 briefly describes the climate change and ocean regimes and the interconnections between them. Part 3 addresses climate change mitigation in relation to the ocean, and Part 4 addresses adaptation. Part 5 concludes by examining whether the climate change regime might do more to address ocean issues.

Before beginning, though, a word of tribute to David Freestone, whose work this volume celebrates. I first met David thirty years ago, when I was a junior lawyer at the State Department, sent to a meeting in the Virgin Islands to negotiate an agreement on specially protected areas and wildlife in the

\footnotetext{
19 As discussed in Section 3.3, ocean law has the primary responsibility of limiting emissions for maritime shipping.

20 See DEJ Currie and K Wowk, 'Climate Change and $\mathrm{CO}_{2}$ in the Oceans and Global Oceans Governance' (2009) 4 Carbon and Climate Law Review 387-404, 392.
} 
Caribbean..$^{21}$ Given the beautiful venue, the interesting subject matter, and the comparatively non-political nature of the issues, the negotiations were not surprisingly - unusually enjoyable. But the element that, for me, sealed the deal, was the Antiguan negotiator: a very amiable English academic, on secondment to the Antiguan government, whose good humour belied a firm negotiating style. David and I hit it off immediately, and spent more than one evening that week sipping David's private stash of Antiguan rum. We have remained good friends ever since, renewing our professional relationship many years later when we served together as co-editors of a Kluwer book series on international environmental law and policy.

David pushed the frontiers of many areas of international law, including both ocean and climate change law. He is among the handful of scholars equally well versed in both fields, and was one of the first to address their interconnections. ${ }^{22}$ This chapter seeks to build on that legacy.

Ocean law is one of the oldest fields of international law. ${ }^{23}$ It first emerged as customary law in the seventeenth century, ${ }^{24}$ and now has been largely codified and elaborated through a heterodox set of treaties. ${ }^{25}$ The Losc serves as its constitution, setting forth, among other matters, the basic rules relating to navigation, maritime boundaries, resource use, scientific research, and protection of the marine environment, and establishing a system of compulsory dispute settlement to resolve ocean issues. Beyond this, ocean law also includes many independent, more specialized treaty regimes, addressing particular issues such as fisheries, ocean dumping, ship-based pollution, and the environmental protection of regional seas.

By contrast to ocean law, climate change law emerged much more recently, over the last quarter century, beginning with the negotiation and adoption of

21 The Protocol concerning Specially Protected Areas and Wildlife in the Wider Caribbean Region was adopted on 18 January 1990, 2180 UNTS 25974.

22 Freestone, 'Climate Change and the Oceans', above (n 18).

23 T Treves, 'Historical Development of the Law of the Sea', in D Rothwell, A Oude Elferink, K Scott and T Stephens (eds), The Oxford Handbook on the Law of the Sea (Oxford University Press, 2016).

24 ED Brown, 'Law of the Sea', in R Bernhardt (ed.), Encyclopedia of Public International Law (North/Holland, 1989) 192.

25 See generally, DR Rothwell and T Stephens, The International Law of the Sea (2nd ed, Hart Publishing, 2017). 
the UN Framework Convention on Climate Change in 1991-1992. ${ }^{26}$ For the purpose of understanding the relationship of the UN climate change regime and the ocean, three features of the climate change regime are worth noting:

- First, it has focused more, in practice, on mitigation than adaptation, even though it gives equal billing to both.

- Second, the regime's approach to mitigation is production-based, allocating responsibility for GHG emissions to the State where emissions occur, rather than based on the nationality of the emitter, the State of origin of the fuel source, or the State where the product resulting from the emission is consumed.

- Third, the regime takes a comprehensive approach, encompassing all sources and sinks of greenhouse gases. ${ }^{27}$ Generally, its rules are formulated in general terms, rather than focusing on particular sectors, gases, policies, or impacts.

By now reaching middle age, the climate change regime has developed in fits and starts. Initially, it followed the example of the ozone regime, and focused on the negotiation of legally binding targets to reduce greenhouse gas emissions, culminating in the adoption of the Kyoto Protocol in 1997. But this approach proved acceptable to only a limited number of countries. In 2009, at the Copenhagen Conference, States agreed to try a different, more widely acceptable paradigm, first put forward in the non-binding Copenhagen Accord ${ }^{28}$ and now encapsulated in legal form in the Paris Agreement. In contrast to Kyoto, the Paris Agreement allows States to nationally determine their mitigation contributions; it breaks down the so-called firewall between developed and developing countries; and it encourages stronger action through transparency and review, rather than by making parties' nationally determined contributions (NDC s) legally binding. ${ }^{29}$

What should be the relationship between ocean and climate change law? Most of the issues arising from the climate change-ocean nexus could potentially be addressed by either or both bodies of law. The effects of climate change on fisheries, for example, could be addressed by regional fisheries organizations as a management issue or by the UN climate change regime as

26 See generally, D Bodansky, J Brunnée, and L Rajamani, International Climate Change Law (Oxford University Press, 2017).

27 The exception is for gases controlled by the 1987 Montreal Protocol on Substances that Deplete the Ozone Layer, 1522 UNTS 3; see UNFCcC, above (n 12), Art 4.1.

28 D Bodansky, 'The Copenhagen Climate Change Conference: A Postmortem' (2010) 104(1) American Journal of International Law 230-240.

Bodansky, Brunnée and Rajamani, above (n 26), chapter 7 . 
an adaptation issue. Similarly, emissions from maritime transport could be addressed by the International Maritime Organization (IMO) or the UN climate change regime or both. Whenever two bodies of law overlap, as ocean and climate change law do, they can interact in a variety of ways, ranging from cooperative to conflictual: ${ }^{30}$

- At one end of the spectrum, they can work synergistically to reinforce one another.

- At the other end of the spectrum, they can come into conflict, with one regime encouraging or requiring actions that the other regime discourages or prohibits.

- In the middle, there can be a division of labour, with particular issues assigned to one regime or the other.

To a limited degree, ocean and climate change law can act synergistically to promote climate change action and, in some cases, they could come into conflict - for example, with respect to ocean fertilization. But, in general, there is a natural division of labour between the two fields, with climate change law focusing on mitigation and ocean law focusing on adaptation.

\section{The Ocean and Climate Change Mitigation}

Climate change mitigation is an archetypal example of a collective action problem. Individual States, on their own, cannot solve the problem, since climate change is a function of total global emissions, not emissions from any individual country. Instead, mitigating climate change requires emissions reductions by all of the major emitting States. ${ }^{31}$ Since climate change first came onto the international agenda in the late 1980s, the UN climate change regime has served as the focal point for international efforts to organize a global response.

What role might ocean law and the ocean itself play in climate change mitigation? Could they be not only a victim of climate change, but also part of the solution, as David Freestone has argued? ${ }^{32}$ In answering this question, it is useful to distinguish three issues:

30 S Oberthür and T Gehring, Institutional Interaction in Global Environmental Governance (MIT Press, 2006); F Biermann, P Pattberg, H van Asselt and F Zelli, 'The Fragmentation of Global Governance Architectures: A Framework for Analysis' (2009) 9(4) Global Environmental Politics 14-40.

31 See generally, S Barrett, Environment and Statecraft: The Strategy of Environmental TreatyMaking (Oxford University Press, 2005); T Sandler, Global Collective Action (Cambridge University Press, 2010).

Freestone, 'Climate Change and the Oceans', above (n 18), 383. 
- First, the potential role of ocean concerns and ocean law in bringing about stronger mitigation action generally.

- Second, the potential emissions reductions from ocean-based activities primarily maritime shipping. The mitigation potential here, although important, is comparatively small, since ocean-based activities are responsible for only a small fraction of total greenhouse gas emissions.

- Third, the potential role of the ocean sink. The ocean removes and stores huge amounts of carbon dioxide, so it could play a significant role in climate change mitigation if humans are able to influence the ocean sink, either by increasing its uptake of carbon dioxide or decreasing the re-release of carbon dioxide back into the atmosphere. However, except for efforts to conserve or enhance so-called 'blue carbon' in coastal waters, the feasibility of influencing the ocean sink remains uncertain.

\subsection{The Role of the Ocean in Promoting Mitigation Generally}

Over the years, a variety of issues have been linked to climate change in an effort to promote stronger action: national security, human rights, and even faith-based concerns. Climate change is a threat multiplier and will provoke or exacerbate conflicts, raising national security concerns. ${ }^{33}$ Climate change will threaten basic human rights, including the rights to life, food, and housing. ${ }^{34}$ Climate change violates the obligation to be good stewards of God's creation. ${ }^{35}$ All of these arguments have been made for doing more to combat climate change.

The adverse impacts of climate change on the ocean provide another good reason to take action against climate change. It is hard to know how much effect this argument will have on public and political debates about climate change. But it is factually correct, could only help, and is therefore well worth making.

Could the impacts of climate change on the ocean be the basis not only for this policy argument for stronger climate action, but also for a legal argument based on the duty of States under the LOSC to preserve and protect the marine

33 CNA Advisory Board, National Security and the Accelerating Risks of Climate Change (May 2014).

34 E Cameron and M Limon, 'Restoring Climate by Realizing Human Rights: The Role of the International Human Rights System' (2012) 21(3) Review of European Community and International Environmental Law 204-219.

35 E Bomberg and A Hague, 'Faith-Based Climate Action in Christian Congregations: Mobilization and Spiritual Hope' (2018) 23(5) Local Environment 582-596; P Francis, Encyclical Letter Laudato Si' on Care for Our Common House (24 May 2015). 
environment? ${ }^{36}$ Greenhouse gas emissions unquestionably cause marine pollution, within the meaning of the LOSC, by introducing substances $\left(\mathrm{CO}_{2}\right)$ and energy into the marine environment. ${ }^{37}$ Article 194 of the LOSC requires States 'individually and jointly' to take 'all measures ... necessary to prevent, reduce, and control pollution of the marine environment from any source, using for this purpose the best practicable means at their disposal and in accordance with their capabilities'. And Articles 207 and 212 focus, in particular, on pollution of the marine environment from land-based sources and through the atmosphere, respectively, requiring parties to 'prevent, reduce, and control' marine pollution from these sources. So the argument that the LOSC requires climate change mitigation has some initial plausibility. ${ }^{38}$

Nevertheless, trying to use the LOSC to make a legal argument for stronger climate action seems to me misguided. As a doctrinal matter, it is unclear what, if anything, the LOSC adds to the obligations States otherwise have to mitigate climate change under international environmental law generally, and climate change law more specifically. General international law requires States to use due diligence to prevent significant transboundary pollution, ${ }^{39}$ and the UNFCCC requires parties to develop policies to mitigate climate change by limiting emissions and enhancing sinks. ${ }^{40}$ Not only does the LOsC fail to add anything to these obligations, it falls well short of the more detailed requirements imposed on parties by the Paris Agreement to develop, maintain, and communicate nationally determined contributions to mitigate climate change; to provide the information necessary to track progress towards achievement of NDC s; and to be subject to international review. ${ }^{41}$ Moreover, as a legal matter, it would be hard to argue that a State that satisfied the requirements of the Paris Agreement was failing to exercise due diligence to prevent climate change

$36 \quad$ Losc, above (n 10), Art 192; see also special issue of the (2019) 34(3) International Journal of Marine and Coastal Law.

37 Losc, ibid Art 1(4) (defining 'marine pollution' as 'the introduction by man, directly or indirectly, of substances or energy into the marine environment ... which results or is likely to result in such deleterious effects as harm to living resources and marine life, hazards to human health, hindrance to marine activities, ... impairment of quality of sea water, and reduction of amenities').

38 Another relevant provision of the LOSC is Article 117, which requires parties to conserve 'the living resources of the high seas'. See generally, A Boyle, 'Law of the Sea Perspectives on Climate Change' (2012) 27(4) International Journal of Marine and Coastal Law 831-838.

39 Legality of the Threat or Use of Nuclear Weapons, Advisory Opinion, (1996) ICJ Reports 226.

$40 \quad$ UNFCCC, above (n 12), Art 4.1.

41 Paris Agreement, adopted 12 December 2015, in force 4 November 2016, [2016] ATS 24, Art 4.2. 
under the LOSC, given that the Paris Agreement has been almost universally accepted by States and represents lex specialis. ${ }^{42}$

In addition to establishing general obligations to prevent, reduce and control marine pollution from land-based sources and through the atmosphere, Articles 207 and 212 require that States 'endeavour to establish global rules, standards and recommended practices and procedures' to prevent marine pollution, 'acting through competent international organizations or diplomatic conferences'.43 Again, however, these provisions provide little help for ocean advocates, since States have arguably already satisfied them through the adoption of the UNFCCC, the Kyoto Protocol, and the Paris Agreement, not to mention the numerous COP decisions fleshing out these agreements.

What the LOsC does add to States' existing obligations under climate change law is a mandatory, binding dispute settlement procedure, ${ }^{44}$ which the UN climate change regime lacks and which could potentially rule on whether States have met their obligation under the LOSC to protect the marine environment. ${ }^{45}$ But even if the LOSC dispute settlement system had jurisdiction over this issue, it would not be a game changer. The United States is not a party to the LOSC, and is not subject to its dispute settlement procedure. China has demonstrated its willingness to boycott the LOsC dispute settlement proceeding in the South China Sea Arbitration and to reject the tribunal's decision, ${ }^{46}$ as has Russia in the Arctic Sunrise case. ${ }^{47}$ So while a judgment on climate change under the LOSC might represent a moral victory for ocean advocates, it is unlikely to change the situation on the ground, inducing States to reduce emissions.

Given the deeply political nature of the climate change issue, an international solution will depend on States coming to agreement to reduce emissions through negotiations, rather than on a tribunal telling States what they

42 Boyle, above (n 38), 835-836.

43 LosC, above (n 10), Arts 207(4), 212(3).

44 Ibid Part XV, section 2 (compulsory procedures entailing binding decisions).

45 M Doelle, 'Climate Change and the Use of the Dispute Settlement Regime of the Law of the Sea Convention' (2006) 37(3-4) Ocean Development and International Law 319-37. Article 138(1) of the Rules of the International Tribunal for the Law of the Sea also provides for advisory opinions pursuant to agreements related to the purposes of the LOSC.

46 S Zhao, 'China and the South China Sea Arbitration: Geopolitics Versus International Law' (2017) 27(109) Journal of Contemporary China 1-15 (describing China's 'four no's': no participation, no recognition, no acceptance, and no compliance).

47 Arctic Sunrise (Netherlandsv Russian Federation), Order of 22 November 2013, ITLos Case No. 22; Arctic Sunrise Arbitration (Netherlands v Russian Federation), Award on the Merits, 14 August 2015, PCA Case No 2014-02. 
are required to do. ${ }^{48}$ International law can serve to memorialize political outcomes and can establish institutions, procedures, and norms that in turn influence the political process going forward. However, international obligations like those found in the LOSC lack the wherewithal to force States to reduce their emissions. For this reason, efforts to use ocean law to argue for stronger climate change mitigation are more likely to be a diversion than helpful.

\subsection{Emissions from Maritime Shipping 49}

The situation is different for emissions from maritime shipping, the principal ocean-based emissions source, which States have decided to address through ocean rather than climate change law. Currently, maritime shipping contributes less than 3 percent of global greenhouse gas emissions, but this number is expected to rise..$^{50}$ Initially, it was unclear whether the UN climate change regime might regulate emissions from maritime shipping. But in 1997, when adopting the Kyoto Protocol, States decided to address these emissions on a sectoral basis through the International Maritime Organization, which has regulatory competence over maritime shipping, rather than under the Protocol. ${ }^{51}$

Several reasons explain why ship-based emissions are different from other greenhouse gas emissions, and are better addressed on a sectoral basis than as part of a country's overall national emissions, the approach taken by the UN climate change regime. On the one hand, uniform sectoral standards have two important benefits. First, given the international character of the shipping industry, they avoid a patchwork quilt of regulation that discourages vessels from operating globally. Second, they provide a level playing field, so that ships operating under different countries' laws do not gain a competitive advantage vis-à-vis one another. On the other hand, maritime emissions do not fit well into the UNFCCC's accounting approach, which attributes emissions to particular countries based on where the emissions occur. Maritime shipping

48 See Boyle, above (n 38), 838 ('Realistically, ... [the LOSC] is not a substitute for further agreement under the UNFCCC'); D Bodansky, 'The Role of the International Court of Justice in Addressing Climate Change: Some Preliminary Reflections' (2017) 49 Arizona State Law Journal 689-712 (arguing for a limited role for the ICJ).

49 This section draws from D Bodansky, 'Regulating Greenhouse Gas Emissions from Ships: The Role of the International Maritime Organization', in HN Scheiber, N Oral, and M-S Kawn (eds), Ocean Law Debates: The 5o-Year Legacy and Emerging Issues for the Years Ahead (Brill, 2018) 478-501.

50 International Maritime Organization, Second Greenhouse Gas Study (IMO, 2000) Figure 1.1.

$5^{1}$ Kyoto Protocol to the United Nations Framework Convention on Climate Change, adopted 11 December 1997, in force 16 February 2005, 2303 UNTS 162, Art 2.2 (stating the intention of the parties to address emissions from marine bunker fuels through the IMO). 
emissions generally take place outside the territory of any State, so they cannot be allocated to countries on a territorial basis. Allocating them on any other basis is problematic because the shipping industry is so international. To which State should one allocate emissions, for example, from a vessel built in Korea, flagged in Panama, owned in Greece, carrying Chinese cargo from Singapore, where it purchases its bunker fuel, to Sydney and then San Francisco? A study of the various options concluded that 'there is no single allocation option that can be regarded as environmentally effective, legally effective, and allowing for fair burden sharing. 52

The IMO also enjoys several institutional advantages over the UN climate change regime in addressing maritime emissions. It already regulates vessel-source pollution through the International Convention for the Prevention of Pollution from Ships, or MARPOL, ${ }^{53}$ which simply needed to be amended to extend to greenhouse gas emissions. It has more technical expertise than the climate change regime about how ship emissions can be reduced. Finally, it actively involves the shipping industry, whose cooperation will be crucial in implementing whatever rules are agreed.

In 2011, the parties to MARPOL adopted amendments to MARPOL Annex VI, regulating air pollution from ships. The amendments elaborated efficiency standards aimed at limiting greenhouse gas emissions, which parties are required to apply to their flag vessels. ${ }^{54}$ In April 2018, the IMO adopted a more general climate change strategy, which calls for the peaking of emissions from maritime shipping as soon as possible and for a reduction by at least 5 o percent from 2008 levels by $205^{\circ} .^{55}$ Although progress in the IMo has been slow, it remains the best venue to address climate change.

\subsection{Blue Carbon, Ocean Sinks, and Ocean Fertilization}

The ocean is by far the biggest active reservoir of carbon on Earth, storing an estimated 40,000 gigatonnes of carbon (GtC), 25-65 times more than the carbon in fossil fuel reserves, $5^{\circ}$ times more than the atmosphere, and 8-10 times more than terrestrial ecosystems. ${ }^{56}$ It is also a huge carbon sink, removing and

$52 \quad$ N Heitman and S Khalilian, 'Accounting for Carbon Dioxide Emissions from International Shipping: Burden Sharing under Different UnfCcc Allocation Options and Regime Scenarios' (2011) 35(5) Marine Policy 682-691.

53 As amended by the Protocol of 1978,1340 UnTs 61.

54 Bodansky, 'Regulating Greenhouse Gas Emissions from Ships', above (n 49), 494-497.

55 IMO, Resolution ME PC.304(72): Initial Imo Strategy on Reduction of G HG Emissions from Ships, adopted 13 April 2018.

$56 \quad$ IPCC, Climate Change 2013: The Physical Science Basis, Contribution of Working Group I to the Fifth Assessment Report of the Intergovernmental Panel on Climate Change, TF Stocker 
sequestering approximately one third of anthropogenic emissions of carbon dioxide. ${ }^{57}$

Although ocean sinks are not, currently, a major focus of climate policy, they potentially could play a significant role in mitigating climate change. Thus far, the two ocean sink issues that have received the most attention are blue carbon and ocean fertilization, which I will consider in turn.

'Blue carbon' refers to carbon captured and sequestered by marine living resources and coastal ecosystems such as mangrove forests, sea grasses, and salt marshes. Although a small fraction of terrestrial biomass, blue carbon is an intense carbon sink, removing as much as six times more carbon than rainforests per unit area. About a third of mangrove, sea grass, and salt marsh areas have already been lost as a result of coastal development, ${ }^{58}$ and between 2 and 7 percent of blue carbon continues to be lost each year. ${ }^{59}$ One study found that cutting the rate of annual loss in half could reduce greenhouse gas emissions by as much as $0.23 \mathrm{GtC}$ per year. Moreover, restoring coastal wetlands to their 1990 levels would sequester an additional $0.16 \mathrm{GtC}$ per year. ${ }^{60}$

In contrast to other ocean sinks, coastal blue carbon fits within the current framework of international climate change law. Under the Paris Agreement, countries may include policies to conserve or enhance blue carbon in their coastal waters in their NDCs. In the first round of NDC s submitted in 2015, 28 countries included coastal wetlands in their mitigation contribution, and 59 included coastal ecosystems in their adaptation strategies. ${ }^{61}$ The 'Because the Ocean' initiative spearheaded by Chile aims to encourage more parties to include blue carbon in their NDC s. ${ }^{62}$ Of course, in order to be counted under the climate change regime, blue carbon mitigation needs to meet the same accounting and review standards applicable to other mitigation actions - a

et al eds (Cambridge University Press 2013) 471 (estimating storage of 40,453 GtC in the ocean, 607-1605 GtC in fossil fuels reserves, $829 \mathrm{GtC}$ in the atmosphere, and $3575^{-4765}$ GtC in terrestrial ecosystems); see also CA Carlson et al., 'Carbon Cycle' in Encyclopedia of Ocean Sciences, 1: 390-400 (2001).

57 N Gruber, D Clement, BR Carter et al., 'The Oceanic Sink for Anthropogenic $\mathrm{CO}_{2}$ from 1994 to 2007 ' (2019) 363(6432) Science 1193-1199.

58 E McLeod, GL Chmura, S Bouillon et al., 'A Blueprint for Blue Carbon: Toward an Improved Understanding of the Role of Vegetated Coastal Habitats in Sequestering CO2' (2011) 9(10) Frontiers in Ecology and the Environment 552-560.

59 C Nellerman, E Corcoran, CM Duarte et al. (eds), Blue Carbon: The Role of Healthy Oceans in Binding Carbon, A Rapid Response Assessment (UNEP, 2009).

6o D Herr and E Landis, Coastal Blue Carbon Ecosystems: Opportunities for Nationally Determined Contributions (IUCN and the Nature Conservancy, 2016) 8-9.

61 Ibid 6, 10-15.

62 See above ( $\left.\mathrm{n}_{15}\right)$. 
problem currently, given measurement uncertainties. But assuming these issues are resolved and it becomes possible to reliably measure carbon flows into and out of coastal ecosystems, then blue carbon mitigation should be treated the same as other mitigation actions under the Paris Agreement, and should be eligible for credits under the new market mechanism established by Article 6.4, which could provide an important source of funding going forward. ${ }^{63}$

That said, the mitigation potential of coastal blue carbon, though worthy of attention, remains comparatively small. By comparison, the mitigation potential of ocean sinks more generally could be very large, assuming they are susceptible to human influence. Currently, the flows of carbon into and out of the ocean are not included in carbon accounting under the UN climate change regime, because they are naturally occurring and there is no basis for attributing responsibility or credit to individual countries. Moreover, they are in 'steady state' and do influence atmospheric concentrations of $\mathrm{CO}_{2}{ }^{64} \mathrm{But}$ if States were able to enhance the ocean sink and thereby reduce atmospheric concentrations of $\mathrm{CO}_{2}$, then the question would arise: should this activity be eligible for crediting under the UN climate change regime?

Whether it is possible to influence the ocean sink and, if so, how, remains uncertain. ${ }^{65}$ The main approach suggested thus far is to fertilize the ocean with nutrients such as iron, phosphates, nitrates, or volcanic ash, in order to increase plant growth and thereby strengthen the biological pump by which atmospheric $\mathrm{CO}_{2}$ is sequestered in the deep ocean. Early proponents of iron fertilization argued that its mitigation potential is huge, ${ }^{66}$ but more recent scientific research suggests a modest upper limit to sequestration, ranging from 1-3.7 $\mathrm{GtCO}_{2}$ per year, with a total capacity of $85-315 \mathrm{GtCO}_{2}$ through the end of the century. ${ }^{67}$ The environmental effects of ocean fertilization are also uncertain, but could include negative impacts on the marine food web, biological productivity, and ocean biogeochemistry. ${ }^{68}$ Given these uncertainties, a recent

63 D Herr, M von Unger, D Laffoley and A McGivern, 'Pathways for Implementation of Blue Carbon Initiative' (2017) 27(S1) Aquatic Conservation: Marine and Freshwater Ecosystems 116-129.

64 National Research Council, Climate Intervention: Carbon Dioxide Removal and Reliable Sequestration (National Academies Press, 2015) 56.

65 Ibid $56-63$.

66 JH Martin, 'Glacial-Interglacial $\mathrm{CO}_{2}$ Change: The Iron Hypothesis' (1990) 51(1) Paleoceanography $1-13$. Martin was quoted as saying: 'Give me half a ton of iron and I'll give you an ice age'. Climate Intervention, above (n 64), 59 .

67 Climate Intervention, above (n 64), 61.

68 Ibid 61-62. 
National Academy of Sciences study concluded that ocean iron fertilization is 'an immature technology' and that, given its 'limitations and unknowns, ... the risks and costs currently outweigh the benefits'.69

Ocean fertilization and other large scale proposals to use the ocean to mitigate climate change are usually characterized as 'climate engineering' - a term with fuzzy boundaries intended to mark out a category of mitigation that differs from 'ordinary' or 'normal' mitigation, such as growing more trees or agricultural crops. Much has been written about the status of climate engineering under international law. ${ }^{70}$ Although international environmental law does not currently contain any legally binding prohibition on ocean fertilization or other climate engineering techniques, ocean fertilization, in particular, has been the subject of a number of non-binding resolutions by the UN General Assembly, ${ }^{71}$ the London Convention and Protocol on ocean dumping, ${ }^{72}$ and the Convention on Biological Diversity. ${ }^{73}$ The most specific action to date has been taken by the parties to the London Convention and Protocol, which have adopted several resolutions on ocean fertilization. A 2008 resolution found that ocean fertilization falls within the scope of the dumping regime and recommended that States not undertake ocean fertilization except for scientific research purposes. ${ }^{74}$ Two years later, the London Convention/Protocol parties adopted a resolution establishing a comprehensive framework to assess the risks posed by scientific research on ocean fertilization. ${ }^{75}$ Most recently, in 2013, the parties to the London Protocol adopted an amendment to prohibit ocean fertilization, except for legitimate scientific research authorized under a permit. ${ }^{76}$ The 2013 amendment, however, is not yet in force and will apply only

69 Ibid 62-63.

$70 \quad$ See, e.g., KScott, 'Regulating Ocean Fertilization under International Law: The Risks' (2013) 7(2) Carbon and Climate Law Review 108-116; R Warner, 'Marine Snow Storms: Assessing the Environmental Risks of Ocean Fertilization' (2009) 3(4) Carbon and Climate Change Law Review $426-436$.

71 See, e.g., UN General Assembly, Resolution 66/231: Oceans and the law of the sea, adopted 24 December 2011, paras 156-157.

72 IMO, London Convention/Protocol Resolution LC-LP.1(2008) on the regulation of geoengineering, adopted 31 October 2008.

73 Convention on Biological Diversity, СвD/COP/DEC/X/33: Biodiversity and climate change (2010), para. 8(w)-(x).

74 London Convention/Protocol, Resolution LC-LP.1, above (n 72 ).

75 IMO, London Convention/Protocol Resolution LC-LP.2(2010) on the assessment framework for scientific research involving ocean fertilization, adopted 14 October 2010.

76 IMO, Resolution LP.4(8) on the amendment to the London Protocol to regulate the placement of matter for ocean fertilization and other marine geoengineering activities', adopted on 18 October 2013 . 
to the 50 States that are parties to the London Protocol, a group that does not include the United States, China, India, or Brazil.

Part 5 of this chapter will argue that the UN climate change regime should recognize ocean-based mitigation actions taking place in areas beyond national jurisdiction, so long as these mitigation actions are measurable, verifiable, and consistent with any other applicable international rules, including those of ocean law. This approach would not exclude ocean fertilization, but would try to avoid conflicts with other regimes. If ocean sink enhancement can provide measurable, verifiable benefits to the climate, without posing unacceptable risks, then the climate change regime should recognize and encourage it, just like other mitigation actions.

Climate change affects the ocean in myriad ways, altering its 'physical, chemical and biological properties'.77 These changes will negatively impact coastal areas, ${ }^{78}$ fisheries ${ }^{79}$ coral reefs, ${ }^{80}$ and other forms of marine biodiversity.

How are these impacts best addressed? In contrast to climate change mitigation, the answer lies more in ocean law than climate change law. The reason is that ocean adaptation, like adaptation more generally, is to a significant degree not climate specific. Instead, it involves general policies to reduce vulnerability and promote resilience, ${ }^{81}$ which are best pursued in the context of more general regimes - for example, addressing emergency preparedness and disaster relief.

In the case of the ocean, adaptation to climate change largely involves reducing other stressors on the marine environment, and through integrated coastal and ocean management. The UN climate change regime plays an important role in encouraging States to undertake adaptation planning and providing support. But to the extent adaptation involves collective action, this is better

\footnotetext{
77 IPCC, Climate Change 2013, above (n 2), 414.

78 RJ Nicholls and Anny Cazenave, 'Sea-Level Rise and Its Impact on Coastal Zones' (2010) 328(5985) Science 1517-1520.

79 IPCC, Climate Change 2014, above (n 9), 5 .

8o Ibid 97-100 (cross-chapter box on coral reefs); O Hoegh-Guldberg, PJ Mumby, AJ Hooten et al., 'Coral Reefs under Rapid Climate Change and Ocean Acidification' (2007) 318(5857) Science 1737-1742.

81 DR Nelson, WN Adger, and K Brown, 'Adaptation to Environmental Change: Contributions of a Resilience Framework' (2007) 32 Annual Review of Environment and Resources 395-419.
} 
pursued through the relevant ocean regimes and coastal zone management, rather than through the UN climate regime, which has little expertise.

Take fisheries as an example. Climate change is expected to change the abundance and distribution of marine species, due to rising temperatures, acidification, and deoxygenation. The only real way to address these impacts other than stopping climate change - is by reducing the non-climate stressors on fisheries, such as overfishing and pollution. The UN climate change regime cannot do so effectively, because these non-climate stressors are beyond the UN climate regime's regulatory competence and expertise. By contrast, regional fisheries management organizations (RFMOs) have the general mandate to conserve and manage fisheries resources, and are better able to do so. ${ }^{82}$ Addressing climate change impacts would not require changing their regulatory competence (although, due to changes in species distribution, climate change might require changes in the respective jurisdiction of RFMO s). Instead, it would simply require RFMOs to consider the impacts of climate change on fisheries and integrate them into their management decisions. ${ }^{83} \mathrm{Of}$ course, as a political and practical matter, this may not be easy to do, as suggested by the fact RFMOs are not currently taking climate change adequately into account. ${ }^{84}$ Nevertheless, RFMOs are better placed than the UN climate change regime to take meaningful action. Regional seas bodies might also play a role in designating marine protected areas.

Adaptation to the impacts of climate change on coral reefs is also better addressed by ocean law than by climate change law. Climate change adversely affects coral reefs by increasing the severity of extreme weather events, increasing ocean temperatures and acidity, and reducing stress tolerance, which all contribute to coral bleaching. Apart from reducing emissions of $\mathrm{CO}_{2}$ and limiting climate change, the only way to protect coral reefs is by reducing other

82 On the role of RFMos in addressing climate change, see M Axelrod, 'Climate Change and Global Fisheries Management: Linking Issues to Protect Ecosystems or to Save Political Interests?' (2011) 11(3) Global Environmental Politics 64-84; B Pentz, M Klenk, S Ogle, and JAD Fisher, 'Can Regional Fisheries Management Organizations (RFMOs) Manage Resources Effectively During Climate Change?' (2018) 92 Marine Policy 13-20; R Rayfuse, 'Climate Change and International Fisheries' in R Caddell and EJ Molenaar (eds), Strengthening International Fisheries in an Era of Climate Change (Hart, 2019) 247-268.

83 As one writer notes, 'since climate change impacts can be moderated by reducing stresses from existing human activities, the effective and transparent implementation by RFMOs of a precautionary and ecosystem approach to fisheries management should, in general, go some way towards alleviating the climate change threat'. Rayfuse, above (n 82), 265.

84 Rayfuse concludes that there is 'little at the moment to suggest that RFMO sare explicitly absorbing climate change in their decision rules for stock assessments and harvest rules, or into their catch allocations'. Ibid 263. 
stressors, such as coastal runoff, overfishing, invasive species, and pollution, which reduce the resilience of reefs to climate change. ${ }^{85}$ Since coral reefs are generally associated with the coastal State, most of these measures are best undertaken at the national level, ${ }^{86}$ with the IMO playing a limited role in designating ship routing measures, and the climate change regime playing a residual role of providing capacity building and financial support.

In addition to harming fisheries, ocean warming will impact biodiversity beyond national jurisdiction (BBNJ) more generally. ${ }^{87}$ For this reason, climate change is an issue in the вв $\mathrm{BN}$ negotiations currently underway. ${ }^{88}$ One possible adaptation measure would be to encourage States to take climate change into account in the design of area-based management tools, such as marineprotected areas ${ }^{89}$ - for example, through the establishment of protected migratory corridors.

Finally, with respect to sea level rise, adaptation largely involves integrated coastal zone management, a subject more in the purview of ocean law than climate change law. ${ }^{90}$ Sea level rise also raises major issues regarding maritime baselines, the limits of maritime zones, and even the continued existence of low-lying island States that will become submerged and disappear. ${ }^{91}$ These issues are squarely within the ambit of the LOsc, and were the subject of an ILA Committee on International Law and Sea Level Rise, whose rapporteur was none other than David Freestone. The panel recommended a new legal rule that, once a coastal or archipelagic State's baselines have been properly

85 G Torda, JM Donelson, M Aranda et al., 'Rapid Adaptive Responses to Climate Change in Corals' (2017) 7(9) Nature Climate Change 627; Hoegh-Guidberg et al., above (n 8o).

86 For an example of an adaptation strategy for coral reefs, see Great Barrier Reef Marine Park Authority, Great Barrier Reef Climate Change Adaptation Strategy and Action Plan 2012-2017 (2012).

87 'Policy Brief: Climate Change in Oceans beyond National Jurisdiction', Nereus Scientific and Technical Briefs (2016).

88 C Payne, 'Biodiversity in High Seas Areas: An Integrated Legal Approach' (2017) 21(9) ASIL Insights.

89 Earth Negotiations Bulletin, 25(122) (30 March 2017) (Tonga emphasized that climate change considerations be taken into account in area designations).

$90 \quad$ IPCC, Climate Change 2014, above (n 9), chapter 5 (coastal zones and low-lying areas); J-P Ducratoy and S Pullen, 'Integrated Coastal Zone Management and Developments from an International, European and United Kingdom Perspective' (1999) 42 Ocean and Coastal Management $1-18$.

91 See generally C Schofield, 'Against a Rising Tide: Ambulatory Baselines and Shifting Maritime Limits in the Face of Sea Level Rise', University of Wollongong Research Online (2009), https://ro.uow.edu.au/cgi/viewcontent.cgi?article=1321\&context=lhapapers; AT Camprubí, Statehood under Water: Challenges of Sea-Level Rise to the Continuity of Pacific Islands'Statehood (Brill, 2016). 
determined in accordance with the Losc, they should not be readjusted due to sea level rise. ${ }^{92}$

Given the existing division of labour between climate change law, which focuses primarily on mitigation, and ocean law, which addresses emissions from maritime transport as well as adaptation to the impacts of climate change, what more might the UN climate change regime do to address ocean issues? Two changes are worth considering.

First, the UN climate change regime should more clearly include in its ambit mitigation and adaptation actions undertaken in a State's exclusive economic zone or on the high seas, including actions to conserve and enhance ocean sinks. The ocean covers 70 percent of the world's surface, and plays a critical role in the carbon cycle. It is unclear the degree to which ocean-based mitigation and adaptation is possible. And measurement and verification pose major challenges. But these are reasons to proceed cautiously, not to exclude the ocean altogether.

It is incorrectly assumed within the UN climate change community that a State's NDC is territorially limited, and that States cannot claim credit under the climate change regime for mitigation and adaptation actions in areas beyond national jurisdiction..$^{93}$ There is no textual basis, however, for this assumption. The UNFCCC requires States to 'formulate, implement, publish and regularly update national and, where appropriate, regional programs containing measures to mitigate climate change, ${ }^{94}$ but it does not limit where these measures may take place. Indeed, the UNFCCC also requires States to 'promote and cooperate in the conservation and enhancement, as appropriate, of sinks and reservoirs ..., including ... oceans as well as other ... coastal and marine ecosystems ${ }^{\prime} 95$ - a formulation that seems to clearly encompass areas beyond national jurisdiction by referring, not merely to coastal ecosystems, but also to ocean and marine ecosystems more generally. Similarly, the Paris Agreement requires parties to implement 'domestic' mitigation measures ${ }^{96}$

92 International Law Association, International Law and Sea Level Rise: Report of the International Law Association Committee on International Law and Sea Level Rise (2018)19.

93 Based on author's personal conversations with government delegates.

94 UNFCCC, above (n 12), Art 4.1(b).

95 Ibid Art 4.1(d).

96 Paris Agreement, above (n 41), Art 4.2. 
and recommends that developed country parties undertake economy-wide absolute emission reduction targets, but does not exclude extra-territorial measures; it requires only that, if a State wishes to get credit pursuant to Article 6 for extra-territorial measures in the territory of another State, it must get that State's authorization. ${ }^{97}$

At the moment, clarifying that the UN climate change regime extends to areas beyond national jurisdiction might not have much immediate effect, since it is unclear what measures, if any, are feasible. But creating the possibility of parties receiving credit for measurable and verifiable actions to conserve and enhance ocean sinks would provide an incentive for further research. And if ocean sink enhancement ultimately did prove feasible, the climate regime might consider creating a mechanism for ocean sinks analogous to the REDD+ mechanism for forests.

Second, the UN climate change regime should address the issue of ocean acidification (OA) by giving special attention to reducing $\mathrm{CO}_{2}$ emissions relative to other greenhouse gases. ${ }^{98}$ Currently, the climate change regime compares emissions of different greenhouse gases solely in terms of their contribution to climate change, as measured by their global warming potential or GWP. ${ }^{99}$ According to this metric, emissions reductions of methane are worth 28 times more than $\mathrm{CO}_{2}$ reductions, on a ton for ton basis; nitrous oxide emissions 264 times more; and sulphur hexafluoride emissions 23,500 times more. ${ }^{100}$ What GWP fails to consider, however, is the special harms to the ocean posed by $\mathrm{CO}_{2}$, which raises ocean acidity when dissolved in seawater. ${ }^{101}$

Ocean acidification has devastating impacts on shellfish and corals, in particular, and the human communities dependent on them. How might the climate change regime better address this problem? By developing a metric to compare greenhouse gas emissions that includes their effect on ocean acidification, not only climate change. This OA metric could help incentivize $\mathrm{CO}_{2}-$ oriented mitigation policies, by allowing States to claim extra credit for $\mathrm{CO}_{2}$ emission reductions, as compared to other greenhouse gases.

$97 \quad$ Ibid Art 6.3.

$98 \quad C f$. N Oral, 'Ocean Acidification: Falling Between the Legal Cracks of UNCLOS and the UNFCCC' (2018) 45(1) Ecology Law Quarterly 9-30.

99 IPCC, Climate Change 2013, above (n 2), s 8.7.1.2.

$100 \quad$ Ibid Table 8.A.1.

101 See Currie and Wowk, 'Climate Change and $\mathrm{CO}_{2}$ in the Oceans', above (n 20), 392. 
The ocean has successfully crashed the climate ball, but it has been less successful in explaining what it wants the UN climate change regime to do to help it. This nagging question has inhibited greater focus on ocean issues within the climate change community. Yes, of course ocean sinks are tremendously important in regulating the climate system, a climate negotiator might respond, and the ocean will be devastated by climate change. But what can the climate change regime do, other than a better job of limiting climate change?

This chapter has begun to try to answer that question. In the shorter term, the UN climate change regime should leave the door open to ocean-based mitigation, so that if and when it becomes possible, States will be able to claim credit for it. In addition, the climate change regime, while continuing to encourage mitigation of all greenhouse gases, should put a thumb on the scale for $\mathrm{CO}_{2}$ emission reductions, in recompense for all the good things the ocean does for the climate. The UN climate change regime cannot do everything; it has its hands full with climate change. But if global climate change policy is to be global, it should pay more attention to the two-thirds of the globe that is blue. 